\title{
クラスプの力学的研究
}

第 2 報 鉤腕の外形・寸法について

山賀 保* 堤 定美** 野首 孝柌*

奥野 善彦*

\section{Mechanical Studies on Clasps}

Part 2. On the Shape of Clasp Arms

\author{
Tamotsu Yamaga*, Sadami Tsutsumi**, Takashi Nokubi* \\ and Yoshihiko Okuno*
}

\section{I. 緒 言}

クラスプに関する力学的解析については多くの研究が 報告されているが，これらには数学的に検討したもの 1 9), 光弾性実験法やストレインゲージを用いて基礎的な

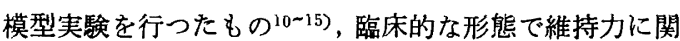

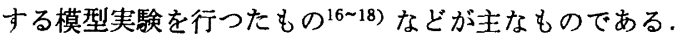

一般にクラスプの力学的特性に影響を及ぼすと考えら れる因子としては, クラスプの外形・寸法, 使用材料の ヤング率, 弾性限度, 弾性エネルギーなどがあげられる。 このなかでクラスプにおける垂直維持力ならびに側方維 持力などへの影響は，第 1 報 ${ }^{19}$ および西山汭が報告して いるように, クラスプの外形・寸法が最も大きいものと 考えられる. 従来クラスプの外形・寸法に関する研究は 種々行わ机ており，主として光弾性実験法を用いて検討 されている．著者の 1 人である奥野 ${ }^{13)}$ は，鋳造鈎の断面 形態は半円形で，しかも鉤体基部より鈎尖部に向かつて 直線的に細くなるものが最も応力分布が均一であり，強

* 大阪大学蔽学部萪科補緅学第 2 辣座 (主任 : 河合庄治郎 教授)

** 大阪大学歯学部歯科理工学講座 (主任 : 山賀礼一教授)

* 2nd Department of Prosthetic Dentistry, Osaka University Dental School, Osaka. (Chief : Prof. Shoji. ro Kawai)

** Department of Dental Technology, Osaka University Dental School, Osaka. (Chief: Prof. Reiichi Yamaga)

昭和 50 年 12 月 1 日受付
じんなクラスプとして適していると述へ，さらにこのこ とを三次元光弾性実験によつて明らかにしている. また 鈎腕の形態は一般にその断面が半円形で，鈎尖から鈎腕 長の $1 / 10$ の部位で鈎腕の幅と厚さは起始部の $1 / 2$ とな るように次第に細くすると言われている ${ }^{21,22) . ~}$

さらに，臨床上用いる鋳造銁の外形・寸法に関して は，エーカースタイプのクラスプの寸法について種々報 告されており 23 26), 河辺ら 24)や旗手ら ${ }^{25)}$ は金合金を基準 とすると, 鈎腕起始部では半径 $1 \mathrm{~mm}$ の半円形, 鈎尖 部では半径 $0.5 \mathrm{~mm}$ の半円形とし, 銁尖部に向かつて 先細りにするものを基本的寸法としている.

しかしこれらの寸法は力学的根拠に乏しく，また臨床 上小臼歯・大臼歯など鉤歯の形態・部位に応じてさらに 多種の外形・寸法規準が必要であり，さらにそれらの機 能力を知つた上で適用する必要がある．このような観点 から現在のところ臨床においてその外形・寸法が十分確 立しているとはいえない. したがつてクラスプの種々の 形態において加えられた力と弾性変形量との関係やささ らに弾塑性変形中の非線型関係などに及ぼす影響を知る ことは臨床においてもきわめて重要なことであると考え られる。

また，口腔内においてクラスプに加わる力の方向はき わめて複雑であるが, 荷重方向を変えて力学的解析をし た報告は宮入ら ${ }^{8,9)}$ が水平荷重と垂直荷重をうけるクラ スプについて報告している程度であり，この点に関して もさらに解明することは意義のあることと考えられる。

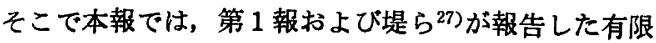


要素法による解析法を応用し，鋳造鉤の外形・寸法を種 々変化させた単純なモデルを設定し，このモデルの 2 次 元平面曲げ問題について，弾性変形ならびに弾塑性変形 の応力と変位を分析し，さらに，荷重方向を変化させた 場合の弾性領域における応力ならびに変位についても検 討した.

\section{II. 実験材料および方法}

実験に用いた鈎腕モデルは断面形態を半円形とし，銁 尖に向かつて漱縮する形態とした．鈎腕の長さを 1 , 銁 腕起始部の半径を $r_{1}$, 銁尖部の半径を $r_{0}$, 漸縮比を $\gamma$ であらわした各鈎腕の寸法は表1のとおりである.A， B, C, D の各銁腕においては, 銁尖から $12 \mathrm{~mm}$ の部分 における半径が $\mathrm{r}_{0}$ の 2 倍に等しくなるよう設定し，こ れらを鈎腕起始部より $2 \mathrm{~mm}$ ずつ短くして各鈎腕を得 たが， $\mathrm{B}^{\prime}$ は B を銁尖から $2 \mathrm{~mm}$ ずつ短くして得たもの である.さらに鋳造銁の基本形態で，このような外形・ 寸法を有し，直線的に漸縮している形態 [直線型]（S） と, 内面の半径を $5 \mathrm{~mm}$ とする 1 種の曲がりはりの形 態 [曲線型]（C）を想定し（図 1)，A，B，C，D，B＇の 5 種類の形態について，それぞれ銁尖部の鈎腕内面に荷 重を加えた。，その荷重条件としては，A，B，C，Dの 4 種類の形態では，それぞれ直線型と曲線型において図 1 に示したように鈎腕内面に対して直角となるような方向 に荷重を加えた．また， $\mathrm{B}^{\prime}$ の形態を用い，直線型と曲線 型において，反時計回わりの方向を十方向と定め，鈎腕

表 1 鉤腕の寸法

\begin{tabular}{|c|c|c|c|c|}
\hline & $l^{\prime}$ & $r_{1}$ & $r_{0}$ & $\gamma\left(r_{0} / r_{\mathbf{l}}\right)$ \\
\hline & 14 & 0.815 & 0.375 & 0.460 \\
$A$ & 12 & 0.750 & & 0.500 \\
& 10 & 0.690 & & 0.543 \\
& 8 & 0.625 & & 0.600 \\
& 6 & 0.565 & & 0.664 \\
\hline & 14 & 1.085 & 0.500 & 0.461 \\
$B$ & 12 & 1.000 & & 0.500 \\
& 10 & 0.915 & & 0.546 \\
& 8 & 0.835 & & 0.599 \\
& 6 & 0.750 & & 0.667 \\
\hline & 14 & 1.355 & 0.625 & 0.461 \\
$C$ & 12 & 1.250 & & 0.500 \\
& 10 & 1.145 & & 0.546 \\
& 8 & 1.040 & & 0.601 \\
& 6 & 0.935 & & 0.668 \\
\hline & 14 & 1.625 & 0.750 & 0.462 \\
$D$ & 12 & 1.500 & & 0.500 \\
& 10 & 1.375 & & 0.545 \\
& 8 & 1.250 & & 0.600 \\
& 6 & 1.125 & & 0.667 \\
\hline & 14 & 1.085 & 0.500 & 0.461 \\
$B^{\prime}$ & 12 & & 0.585 & 0.539 \\
& 10 & & 0.665 & 0.613 \\
& 8 & & 0.750 & 0.691 \\
& 6 & & 0.835 & 0.770 \\
\hline
\end{tabular}

内面に直角方向, 寸なわち傾角 $\varphi=0^{\circ}$ と, 鈎腕起始部 方向および鈎尖方向にそれぞれ $30^{\circ}$ 傾けた $\varphi=+30^{\circ}$ ， $-30^{\circ}$ の 3 方向に, 荷重方向を変化させた場合について も検討した。

なお，これらモデルの材料定数は，市販の歯科用コバ ルトクロム合金のカタログ值より，ヤング率 $\mathrm{E}=25,200$ $\mathrm{kg} / \mathrm{mm}^{2}$, 降伏点 $\sigma_{0.2}=57.6 \mathrm{~kg} / \mathrm{mm}^{2}$, ポアソン比 $\nu=$ 0.33 とし，解析に注京都大学大型計算機センター FA. COM 230-60 型ならびに大阪大学大型計算機センター NEAC 2200 モデル 700 を使用した.

次にこの解析精度と実際の鋳造体とを比較するために 有限要素法と同じ材料を用いて，モデルを直線型とし， その長さを $8,10,12,14 \mathrm{~mm}$ となるような試料を各々 5 個ずつ高周波溶解の遠心鋳造で作製した。この試料の 曲げ試験には図 2 に示したようにインストロン万能材料 試験機を用い，クロスヘッドの送り $0.5 \mathrm{~mm} / \mathrm{min}$, チャ

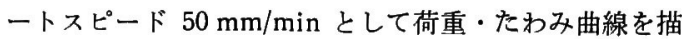
$\mathrm{B}(\mathrm{S})$
$B^{\prime}(S)$
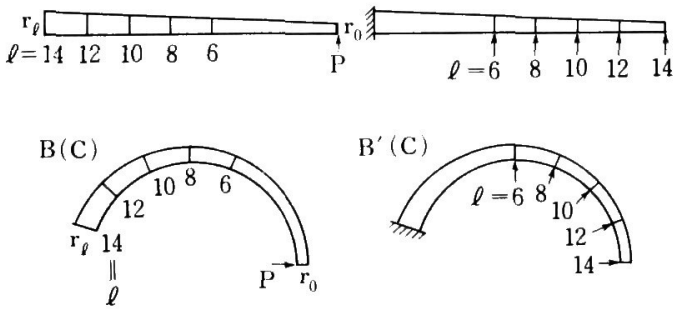

図 1 鈎腕の外形

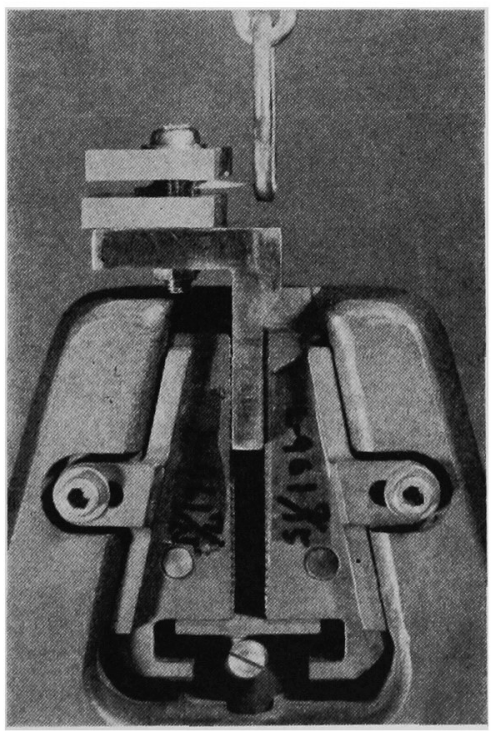

図 2 鈎腕の曲げ試験装固 
$160-620$

かせ, この曲線から弾性限度の荷重量およびたわみ量を 計測し，この値を実験値 (Exp. Value) とした.

また，有限要素法と実験値との比較において，有限要 素法による值 (FEM 值) はインストロン万能材料陚験 機にて引張り試験を行って得た降伏点 $(45.5 \pm 3.3 \mathrm{~kg} /$ $\left.\mathrm{mm}^{2}\right)$ を in put して求めた值とした.

\section{III. 実験結果ならびに考察}

実験結果を, 荷重が鈎腕内面に対して直角方向に加わ った場合と，荷重方向を変化させた場合とにおける応力 分布, 降伏荷重ならびに荷重 $1 \mathrm{~kg}$ 当りの変位の項目に 分類し,これらにおよぼす鈎腕の外形・寸法の影響につ いて考察する.

1. 荷重を鈎腕内面に対して直角方向に加えた場合

(1) 応力分布

鈎腕断面の太さが応力分布に及ぼす影響について本法 を用いて解析した結果，直線型あるいは曲線型における A， B， C，D 4 種類間の応力分布の形状は，ほぼ同様の 傾向にあつた.そこでAの形態を用いて直線型と曲線型 との応力分布を比較検討した.

まず直線型では銁腕の長さ方向を $\mathrm{x}$ 方向，厚さ方向を $\mathrm{y}$ 方向と定め, 鈎腕起始部では $\mathrm{x}$ 方向, $\mathrm{y}$ 方向ともに動 きを拘束し，鈎尖部の鈎腕内面において直角方向（y 方 向）に荷重を加えた場合の A-14 mm における鈎腕外面 と内面における応力值を図 3 に示した. $\mathrm{x}$ 方向の応力 を， $\sigma_{x}, y$ 方向の応力を $\sigma_{y}$ で表わし，さらにせん断応 力 $\tau_{x y}$ も考虑し，これらを組み合わせ一軸方向の応力 值に換算した応力値を相当応力 $\bar{\sigma}$ とし，これを

$$
\begin{aligned}
\bar{\sigma} & =\sqrt{\frac{1}{2}}\left[\left(\sigma_{y}-\sigma_{z}\right)^{2}+\left(\sigma_{z}-\sigma_{x}\right)^{2}+\left(\sigma_{x}-\sigma_{y}\right)^{2}\right] \\
& \left.+6\left(\tau_{y z}^{2}+\tau_{x z}^{2}+\tau_{x y}^{2}\right)\right]^{1 / 2} \ldots \ldots \ldots \ldots \ldots \ldots \ldots \ldots \ldots \ldots
\end{aligned}
$$

であらわした．降伏現象は von Misses の降伏条件によ りこの相当応力 $\bar{\sigma}$ で評価した．また荷重を増加する場 合, 少くとも 1 つの要素が降伏しはじめた時を Stage 1 とし，その時の応力值を $\sigma_{x 1}, \sigma_{y 1}, \bar{\sigma}_{1}$ であらわした. さ らに荷重を増加させ, 少くとも 10 個の要素が降伏する 時を Stage 10 とし, その時の応力値を $\sigma_{\mathrm{x} 10}, \sigma_{\mathrm{y} 10}, \bar{\sigma}_{10}$ であらわした。

その結果, $\mathrm{x}$ 方向の応力 $\sigma_{\mathrm{x}}$ では鈎腕の外面は圧縮, その内面は引張りとなるが, $\mathrm{y}$ 方向の応力 $\sigma_{\mathrm{y}}$ は $\sigma_{\mathrm{x}}$ K 比べて小さい值を示した．また応力はモデル全体に比較 的均一に分布していることがわかつた. 次に降伏が起こ

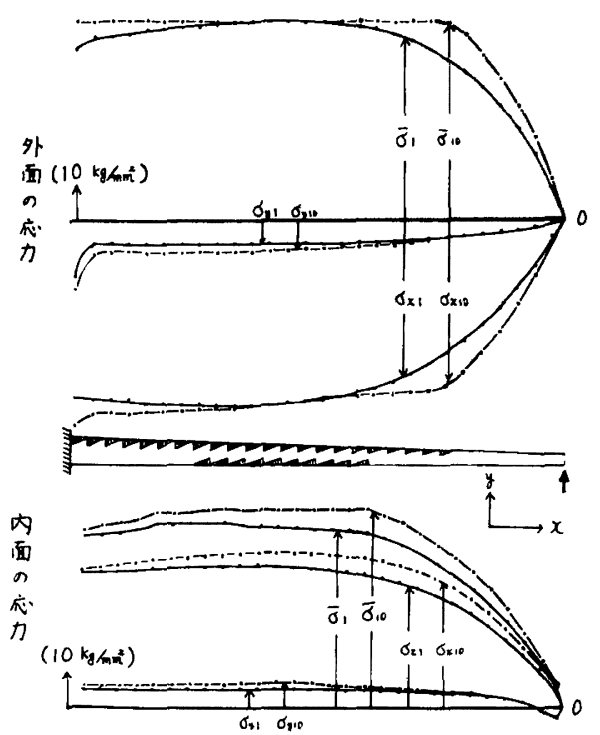

図 4 直線型 A-14 mm の内・外面におおる応力 分布と降伏した要素.

一は Stage 1 で降伏しはじめた要素を， は Stage 10 までに降伏した要素を示す.

る部分は鈎腕長のほぼ中央外面から始まるが，さらに荷 重を増加すると, 鈎腕全体に降伏現象が搪がつて行くの がみられた。ま，鈎腕の長さを鈎腕起始部から $2 \mathrm{~mm}$ ずつ短くしていった場合も，その応力分布は A-14 mm の場合とほぼ同様の傾向を示した。

一方, 曲線型化おいて鈎尖部の鈎腕内面に直角方向 （曲線型においてはこの方向を $\mathrm{x}$ 方向，その方向から反 時計回りに $90^{\circ}$ の方向をy 方向と定めた) に荷重を加え た場合の応力分布ならびに降伏した要素は図 4 に示した

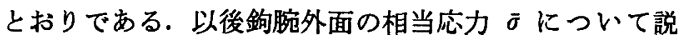
明すると，直線型と異なり鈎尖寄りに応力の集中する傾 向がみられ (Stage 1), さらに荷重を増加させてもこの 部分を中心に降伏が起こっている (Stage 10). また鈎 腕の長さを $2 \mathrm{~mm}$ ずつ短くするにつれて鈎腕の形態は 直線型に近くなり，図 5 に示したとおり，直線型の場合 とよく似た応力分布を示し, 鈎腕起始部における応力值 は大きくなる傾向を示した，直線型と曲線型の鈎腕断面 は同一で, 荷重方向もともに鈎腕内面に対して直角方向 に設定したにもかかわらず，このように応力分布に差が みられた主な原因としては，直・曲の外形の違いによる ものと考えられる.

また直線型における最初の降伏位置, すなわち Stage 1 の降伏要素は，第 1 報で報告した理論解における渐縮 比 $\gamma$ から求めた最大応力を示す位㯰 $\mathrm{x}_{\boldsymbol{a m a x}}$ の近傍に分 


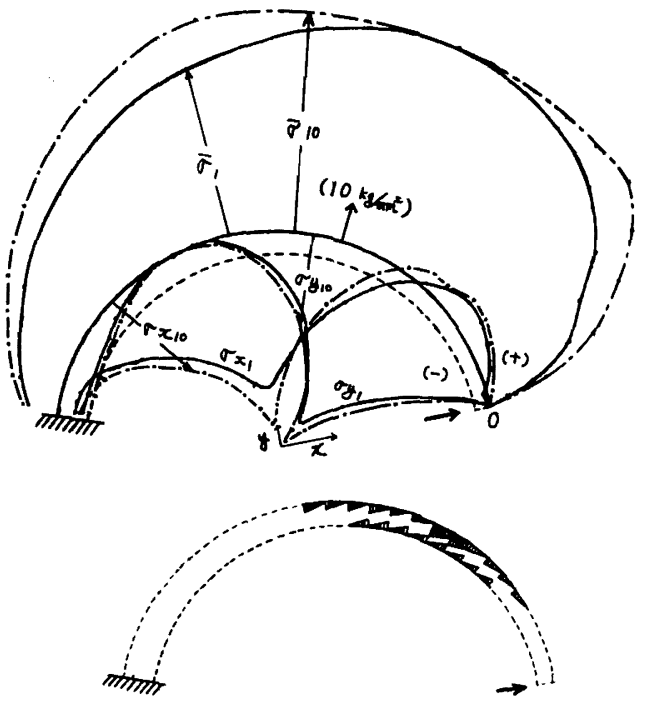

図 4 曲線型 $\mathrm{A}-14 \mathrm{~mm}$ の外面におおる応力分布と降 伏した要素.
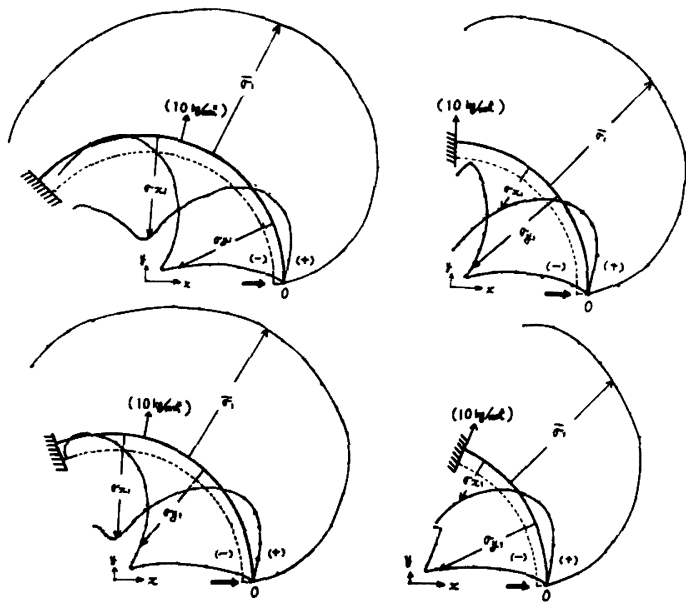

図 5 曲線型 $\mathrm{A}$ において鈎腕の長さ1を $2 \mathrm{~mm}$ ずつ変化 させた場合の応力分布.

布しており（図3）, 有限要素法の解は理論解と同様の 傾向を示すことがわかつた.

（2）降伏荷重

図 6 は降伏に要する荷重Pを示したもので, 直線型 （S）では A，B，C，Dいずれの形態においても，各鈎 尖部の断面半径を同し寸法にした場合，長さに関保なく ほほ一定の荷重で降伏し，鈎尖部の断面半径が， A， B, C, D と太くなるにつれて降伏荷重はBは Aの 1.87 倍, $\mathrm{C}$ はBの 1.69 倍, $\mathrm{D}$ はCの 1.37 倍と増加した.

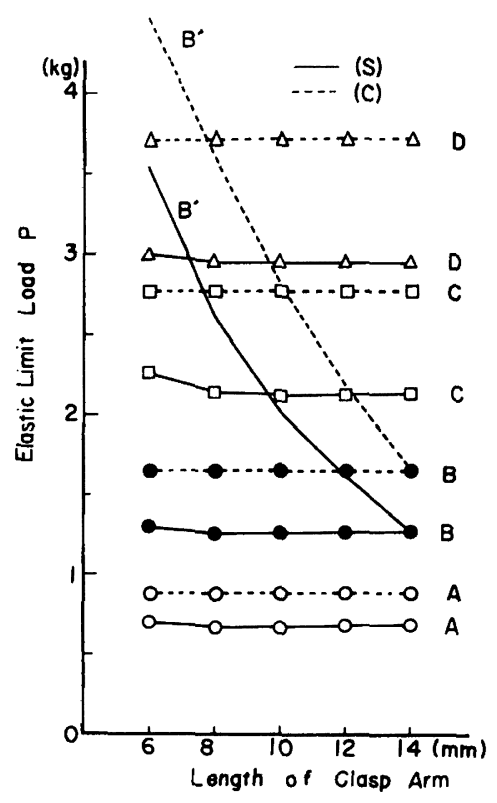

図 6 降伏荷重 ( $\mathrm{S}$ : 直線型, $\mathrm{C}$ : 曲線型)

第 1 報で求めたように直線型における最大応力值 $\left(\sigma_{\max }\right)$ の理論式は次の式で表わされる.

$$
\sigma_{\max }=\frac{-4 \times \mathrm{P} \times 1}{27 \times 0.1908 \times \mathrm{r}_{0}^{2} \times\left(\mathrm{r}_{1}-\mathrm{r}_{0}\right)}
$$

また鉤尖部の断面半径 $r_{0}$, 銁腕起始部の半径 $r_{1}$ および 鈎腕の長さ 1 との関係は, 本実験では鈎尖から $12 \mathrm{~mm}$ のところの断面半径が鉤尖部の半径 $\mathrm{r}_{0}$ の 2 倍となつて いるので(2)式を整理すると，

$$
\mathrm{P}=\frac{27 \times 0.1908}{12 \times 4} \times\left(-\sigma_{\max }\right) \mathrm{r}_{0}^{3}
$$

となり, 降伏に要する荷重 $\mathrm{P}$ は, 降伏時の応力値 $\sigma_{0 \cdot 2}=$ $\sigma_{\max }$ か $57.6 \mathrm{~kg} / \mathrm{mm}^{2}$ と一定であるため, 鈎腕の長さに 関係なく鉤尖の半径 $\mathrm{r}_{0}$ の 3 乗に比例することがわか

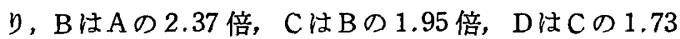
倍であり, 我々の解析結果の太さの違いによる比率は理 論解のそれよりを低い值を示した。

一方, 鈞腕起始部の半径 $\mathrm{r}_{1}$ を一定として, 鉤腕の長 さを変化させた場合 $\mathrm{B}^{\prime}$ について同様に理論式(2)式を整 理すると，

$$
\mathrm{P}=\frac{27 \times 0.1908 \times 12^{2}}{4(12+1)^{3}} \times\left(-\sigma_{\max }\right) \mathrm{r}_{1}^{3}
$$

となり，降伏荷重 P は钧腕の長さ 1 および鉤腕起始部の 半径 $r_{1}$ の関数で表示できる. $B^{\prime}$ の場合鉤腕起始部の半 径 $\mathrm{r}_{1}$ は一定であることから, 降伏荷重 $\mathrm{P}$ 江鈎腕の長さ 1 を $2 \mathrm{~mm}$ ずつ短くするにつれて理論的には 1.27〜 1.37 
$162-622$

倍増加することになる．解析結果においても降伏荷重は 鉤腕の長さを $2 \mathrm{~mm}$ ずつ短くするにつれて，1.25〜1.37 倍と増加し, 両者ともほぼ同様の比率で増加しており有 限要素法による解はいずれの場合においても理論解と同 様の傾向を示すことがわかつた。

一方, 曲線型の場合は理論的表示は現在の段階では困 難であるが, 図 6 に示したように, 鈎尖部の半径 $\mathrm{r}_{0}$ を同 一にした場合, 鈎腕の長さに関係なくほぼ一定の荷重量 で降伏し, 鉤尖部の半径が太くなるにつれて, 降伏に要 する荷重 $\mathrm{P}$ は $\mathrm{B} か 3 \mathrm{~A} の 1.87$ 倍, $\mathrm{C}$ が $\mathrm{B}$ の 1.68 倍, $\mathrm{D}$ が $\mathrm{C} の 1.34$ 倍と増加した. また鈎腕起始部の半径 $\mathrm{r}_{1}$ を 一定にした $B^{\prime}$ の曲線型においても鈎腕の長さを $2 \mathrm{~mm}$ ずつ短くするにつれてその荷重 P は 1.24 1.31倍と増 加し, いずれも直線型と同様の倍率を示し, 直線型の場 合より曲線型の方が $3 〜 4$ 割高い值を示した.

（3）荷重 $1 \mathrm{~kg}$ 当りの変位

図 7 は荷重 $1 \mathrm{~kg}$ 当りの変位を示したものであり, 銁 腕が長くなるほど，また断面が細いほど変位は大きくな つたが, 比率は $6,8,10,12,14 \mathrm{~mm}$ では $2 \mathrm{~mm}$ ずつ 長くするにしたがって, 1.26〜1.29 倍, 1.35〜1.38倍, 1.49 1.63 倍, 1.76〜1.82 倍となつた。第 1 報で報告 したたわみ曲線の理論解

$$
\delta=\frac{\mathrm{P} \cdot 1^{3}}{3 \times 0.1098 \cdot \mathrm{E} \cdot \mathrm{r}_{0} \cdot \mathrm{r}_{1}^{3}}
$$

に扔いては, 1.24〜1.25 倍, $1.32 \sim 1.50$ 倍, $1.45 \sim 1.48$ 倍, 1.71〜1.75 倍であり, それぞれの比率はかなり良く 一致し, 理論解と同様の傾向を示した. しかし， 4 種の 断面形態 $\mathrm{A}, \mathrm{B}, \mathrm{C}, \mathrm{D}$ の間では, $\mathrm{A}$ は B の 2.30 2.40 倍, $\mathrm{B}$ は C の 2.07〜2.20 倍, $\mathrm{C}$ は Dの 1.69〜1.88倍を 示しているのに対して, 理論解ではそれぞれ 3.11〜3.18 倍, 2.42 2.45 倍, $2.07 \sim 2.90$ 倍を示し, それぞれの 比率はとくに断面の細い方が小さくなる傾向を示した.

これは第 1 報から計算精度が $\mathrm{A}, \mathrm{B}, \mathrm{C}, \mathrm{D}$ の間では異な つて評価され, 細い方が有限要素法の計算精度が低いこ とに起因しているものと考えられる.

一方, 直線型と曲線型における変位を比べると銁腕が 短い場合はその差が小さかつたが，長くなるにつれて直 線型の方が曲線型より変位量が大きくなり, 同じ外形寸 法を有していても，Bates ${ }^{28)}$ が報告したように銁腕が彎 曲すると変位しにくくなり，その曲の度合によつて変 位量に対し影響を及ぼすものと考えられる。これは応力 分布において, 直線型では銁腕全体に応力がほぼ均一に 分布する傾向を示したのに対して，曲線型では銁尖寄り に応力の集中する傾向を示したことから説明でき，変位

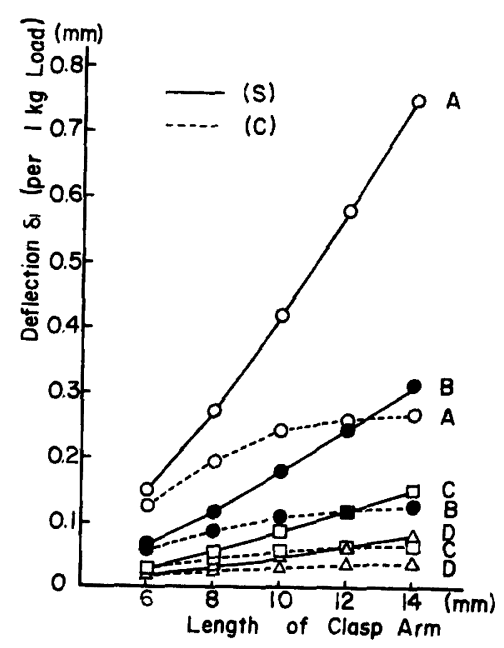

図 7 荷重 $1 \mathrm{~kg}$ 当りの変位 $(S:$ 直線型, $\mathrm{C}:$ 曲線型)

量と応力分布とはよく対応しているものと思われる.

(4) 実験値と FEM 值

図 8,9 淔線型において有限要素法モデル A, B , C, $\mathrm{D}$ と同一形態の試料をコバルトクロム合金で鋳造し，そ の鋳造体をインストロン万能材料試験機で曲げ試験を行 つた実験值 (Exp. Value) と, その鋳造体の降伏点を input した有限要素法による計算值 (FEM Value) と を比較したものである。

降伏荷重において（図 8), 鈎尖部の半径が同じ場合， 有限要素法の計算結果と同様に実験値でも, 銁腕の長さ に関俰なくほぼ一定の值で降伏し, 鈎尖部の半径が太く なるにしたがい BはAの 2.55 倍, C は Bの 1.89 倍, D はCの 1.67 倍と增加し, 実験值におけるこの比率は理 論解の比率とほぼ一致しておう，FEM 値も各々の計算 精度で $\alpha$ 修正すれば両者に合致することがわかつた。

荷重 $1 \mathrm{~kg}$ 当りの変位に扔いては (図 9 ), 実験値と FEM 值を比較するとAにおいて值はかなり差がみら れた.ここで第 1 報で報告した形状係数 $\beta$ から $\alpha$ を求め て FEM 值を修正すると, A-14 mm のように理論值に 対して約 $45 \%$ と大きな差がみられたものが，実験值よ り約 1 割大きな值になり，FEM 值は実験值にかなり近 似した. 一方, 鈎腕断面が太い B，C およびDでは FEM 值は理論值の $60 \sim 80 \%$ に相当しており, 計算結果を修 正すると実験値とほとんど一致することがかかつた. し たがつて実験的にも理論的にも解析することが困難な形 態に対しても, 形状係数 $\beta$ から計算精度 $\alpha$ が推定可能 である場合に，有限要素法を用いれば解析は可能とな 


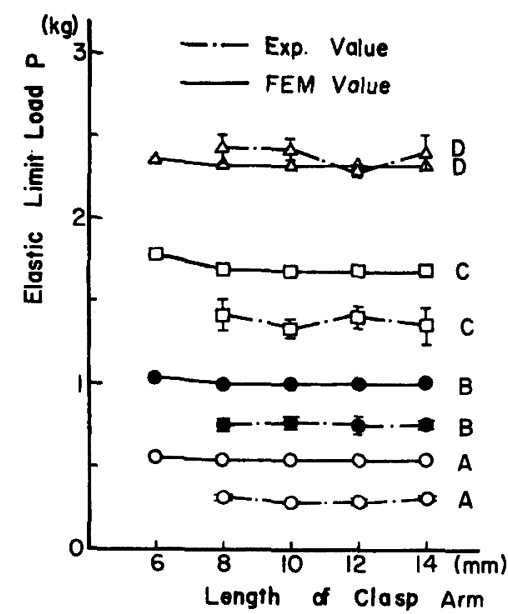

図 8 降伏荷重（実験値と FEM 値）

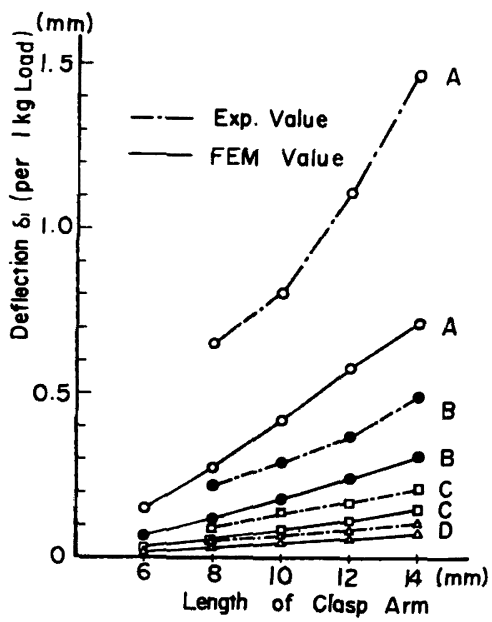

図 9 荷重 $1 \mathrm{~kg}$ 当りの変位 (実験值と FEM 值)

り，きわめて有効な方法であると考えられる。

\section{2. 荷重方向を変化させた場合}

口腔内の種々の機能によつて義菌は動摇し,クラスプ に対してはかなり複雑な力が作用するものと考えられ

る. そこで前述の 5 種類の形態のうち, 今回 $B^{\prime}$ の形態 を用い荷重方向を $\varphi=0^{\circ}, \pm 30^{\circ}$ と変化させた場合の応 力分布と変位について比較検討した. すなわち反时計回 わりの方向を十方向と定め, 鈎腕内面に直角方向 $\varphi=0^{\circ}$ 々, その方向から鈎腕起始部方向および鈎尖方向にそれ ぞれ $30^{\circ}$ 傾けた $\varphi=+30^{\circ},-30^{\circ}$ の 3 方向とした.

(1) 応力分布

直線型において， $0^{\circ}$ 方向に荷重を加え钧腕の長さを

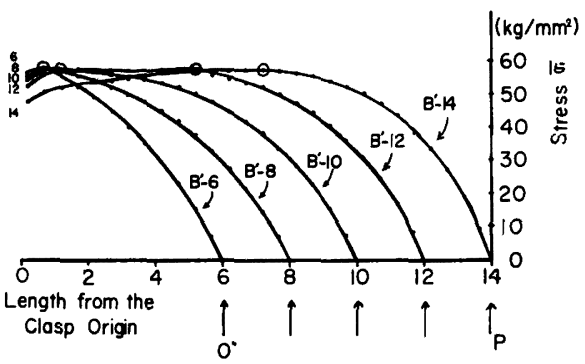

图 10 直線型 $\mathrm{B}^{\prime}$ において垂直方向 $\left(0^{\circ}\right)$ に荷重 を加え, 鈎腕の長さ 1 を $2 \mathrm{~mm}$ ずつ変化 させた場合の応力分布 (O印は最大応力を あらわす位膡).

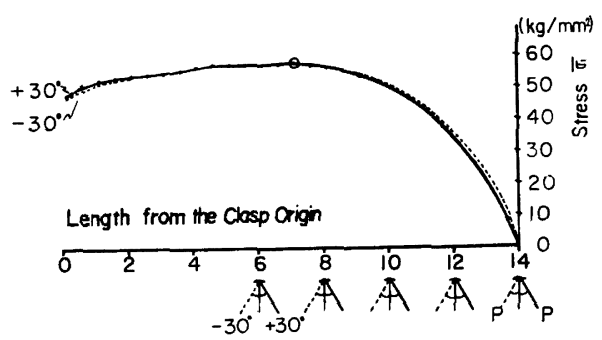

図 11 直線型 $B^{\prime}$ において荷重方向を $\pm 30^{\circ}$ に変 化させた場合の応力分布.

種々変化させた場合（図 10), 最大応力を示す位置は銁 腕の長さが $14,12 \mathrm{~mm}$ ではその長さのほぼ中央の部分 に見られたが，10，8，6 mm と短くするにしたがって銁 腕起始部付近になつた. これらは第 1 報で報告した理論 解における漸縮比 $\gamma$ と最大応力を示す位置 $\mathrm{x}_{\boldsymbol{\theta} \text { max }}$ との 関倸と近似した結果を示した．しかし理論解において漸 縮比 $\gamma$ が $1 / 1.5$ よりも大きくなつている銁腕長, 8,6 $\mathrm{mm}$ では最大応力は鈎腕起始部にみられる. しかし, 有 限要素法の解は 1 つの要素内に生じる応力分布の平均值 であらわされているため, 鈎腕起始部の応力値を知るこ とができず，したがって計算結果は銁腕起始部を含んだ 各要素の応力值として表わされるため, 最大応力は鈎腕 起始部から 1 つ手前の要素にみられたものと考えられ る.

次に, 荷重方向を $+30^{\circ},-30^{\circ}$ と変化させた場合, 直線型では応力分布は荷重方向 $0^{\circ}$ の時とほとんど差が みられず，いずれも鉤腕全体に応力の分散がみられた (図11).

しかし，曲線型においては（図 12），最大応力を示す 位固は $0^{\circ}$ 方向荷重時と比較して, $-30^{\circ}$ 方向の荷重時 では钩尖部寄りに移動し， $+30^{\circ}$ 方向の荷重時では鈎腕 起始部奇り一移動しており，その部分を中心として応力 
$164-624$

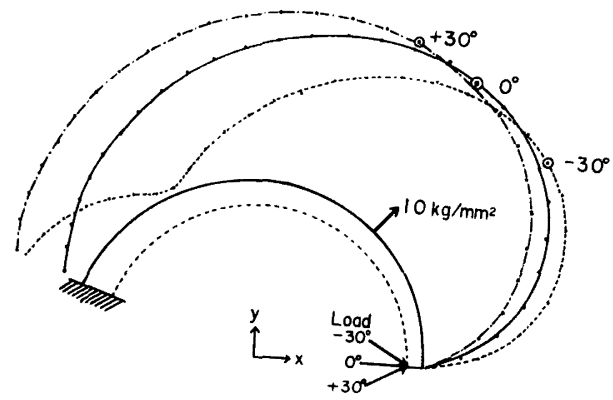

図 12 曲線型 $\mathrm{B}^{\prime}-14 \mathrm{~mm}$ において荷重方向を $0^{\circ}, \pm 30^{\circ}$ に変化させた場合の応力分布.

の集中する傾向がみられ，直線型における応力分布状態 とは異つた傾向を示した．また曲線型における $-30^{\circ}$ 方 向の荷重時ではとくに鈎尖部寄りに応力の集中する傾向 が強く, 5 種の鈎腕長のうち $12,14 \mathrm{~mm}$ では鈎腕起始 部付近において応力値が低下した.これは，曲線型一 $30^{\circ}$ 方向の荷重時では鉤腕長が $12,14 \mathrm{~mm}$ の場合, 拘 束部位における反力を求めてみると，この 2 者以外のモ デルと符号が逆転しており，中立軸から鈎腕外側で引張 りカが，また銁腕内側で圧縮力が生じていた.すなわち， 鉤腕起始部での曲げ応力は, 鉤尖部寄りで発生している 曲げ応力と反対の方向となつており，したがつて，これ らの打消しあう位置 (鈎尖から約 $10.5 \mathrm{~mm}$ ) において 相当応力が低下したものと考えられる.

（2）降伏荷重

荷重を銁腕内面に対し直角方向に加えた場合，降伏に 要する荷重については先に検討したが, 荷重方向を変化 させた場合の降伏に要する荷重（図 13）は曲線型におい てその影響がみられ，その荷重量はー $30^{\circ}$ 方向の荷重時 で最も大きく,ついで $0^{\circ}$ 方向の荷重時であり，応力の集 中する傾向がゆるくしかも鈎腕起始部で応力値が高い+ $30^{\circ}$ 方向の荷重時では小さく, 直線型における $\pm 30^{\circ}$ 方 向の荷重時とほぼ同程度の荷重量であつた。また直線型 には荷重方向の影響はほとんど表われなかつた.

しかしながら，直線型・曲線型とも鈎腕の長さを 2 $\mathrm{mm}$ ずつ短くするにしたがつて降伏荷重の増加する比 率は, 荷重方向が変化しても, $\varphi=0^{\circ}, \pm 30^{\circ}$ 方向の荷 重時ともほとんど変化しなかった．また直線型と曲線型 のそれを比べても, 直線型では 1.25〜1.38倍であり, 曲線型では 1.24〜1.34 倍であり, 比率においては荷重 方向の影響はほとんどないものと考えられる。

（3）荷重 $1 \mathrm{~kg}$ 当りの変位

荷重 $1 \mathrm{~kg}$ 当りの変位（図 14）では，応力の集中する 傾向の強い曲線型で $-30^{\circ}$ 方向の荷重時が最も変位しに

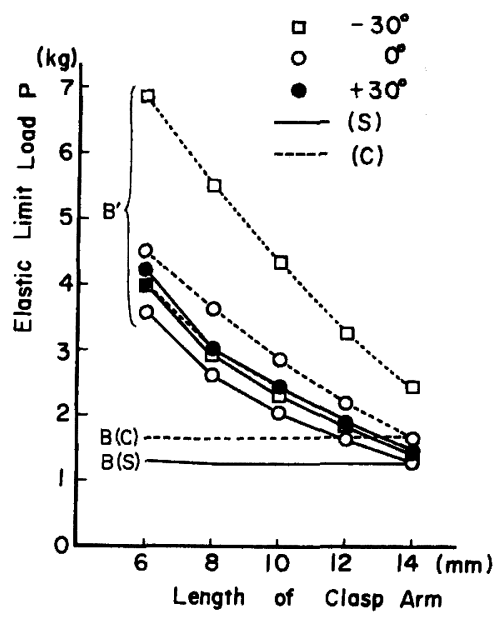

図 13 荷重方向を変化させた場合の降伏 荷重

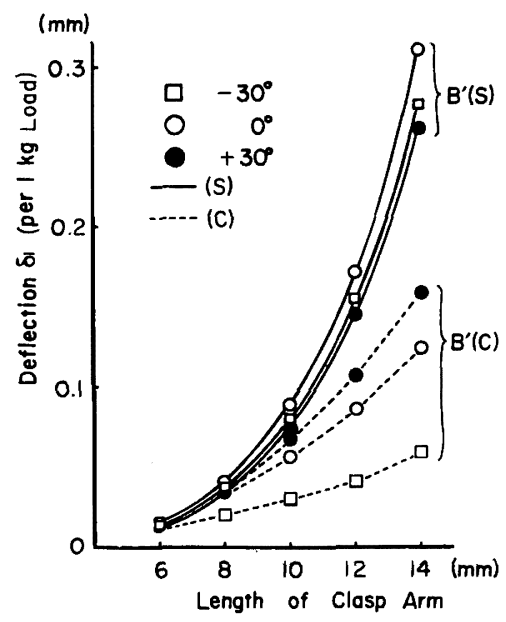

図 14 荷重方向を変化させた場合の荷重 $1 \mathrm{~kg}$ 当 $り$ 変位

くく, $0^{\circ},+30^{\circ}$ 方向の荷重時がついで変位しにくい傾 向を示した. 一方, 応力がモデル全体にほぼ均一に分布 する直線型ではこれらと比較して変位しやすいことがわ かつた.

荷重方向の影響は曲線型にみられるが，直線型にはほ とんど表われず, また荷重方向を変化させた場合も荷重 $1 \mathrm{~kg}$ 当りの変位と応力分布とはよく対応していた。

曲線型の $-30^{\circ}$ 方向荷重では，荷重を $0^{\circ}$ 方向および $-90^{\circ}$ 方向の分力に分解できる. このうち $0^{\circ}$ 方向の分 力は鈎腕を変位させる方向に働き，一方 $-90^{\circ}$ 方向の分 力は鉤腕の形態および拘束部位の影響により鈎腕を内面 
に押しつける方向に向かい，変位させないように働くも のと考えられる. その形態からみてこの分力の影響の大 きな $12,14 \mathrm{~mm}$ では拘束部位において反力が逆転し， また最も変位しにくい傾向を示し，忘力の集中する傾向 も大きくなつたものと考えられる. 曲線型の $+30^{\circ}$ 方向 荷重では, $-30^{\circ}$ 方向荷重と同様に $+90^{\circ}$ 方向の分力が 発生するけれども，この分力は $0^{\circ}$ 方向の分力とともに 鈎腕を変位させる方向に働くので $0^{\circ}$ 方向荷重よりも， 变位しやすくなり，応力の集中する傾向も他の 2 者の荷 重方向に比較してゆるくなつたものと考えられる.

\section{IV. 結 論}

クラスプのカ学的解析に有限要素法を適用し, クラス プの長さおよび断面の半径，ならびに荷重方向の影響を 検討するために，直線型ならびに曲線型における 2 次元 平面曲げ問題として弾塑性変形の応力と変位を計算し た. その結果を要約すると次のとおりである.

（1）直線型においては相当応力はモデル全体にわたつ てほぼ均一に分布したが，曲線型では銁尖寄りに応力の 集中する傾向がみられた。 また曲線型は直線型よりもた わみにくい形態であつた.

（2）鉤尖部の半径を同一にして鈎腕の長さを変化させ た場合，降伏に要する荷重はその長さに関係なく一定の 值であつた．また鉤腕起始部の半径を同一にして鈎腕の 長さを変化させた場合は，降伏に要する荷重はその長さ により影響をうけ，鉤腕が短くなるにしたがつてその值 は增加した.これらは直線型・曲線型ともほとんど同様 の傾向がみられた。

（3）荷重方向を変化させた場合，応力分布ならびに変 位において曲線型ではこの影響が表われたが，直線型で はほとんど変化がみられなかつた。

（4）有限要素法で得た值を，第 1 報で報告したような 適当な形状係数を考虑して修正すれば，理論解ならびに 実験値にほぼ近似できることがわかり，実験的にも理論 的にも解析の困難な形態に対してこの解析法を適用する ことは非常に有効であると考えられる.

\section{文献}

1）河辺清治：線鈎，東京，昭和 28，歯科呯碖.

2）三浦維四：クラスプの力学的理論，口病誌，23：179 180, 昭 36 (1961).

3）福井彰一: クラスプの力学的解析, 邀材呼報, $2: 161$ 173, 昭 35 (1960).
4）村松第良，安達和子：切り口を有する変断面円㻴の曲げ (cast clasp 設計への一奇与), 每理工誌， $3: 51 \sim 55$, 昭 37 (1962).

5) Warr, J.A. : An analysis of clasp design in partial dentures, Phys. in Med. Biol., $3: 212 \sim$ 232, 1959.

6) Warr, J.A. : Numerical system of clasp design, J. Pros. Dent., $11: 1105 \sim 1111,1961$.

7）宝田 勇：クラスプの維持力に関する研究，歯科学報, $64: 148 \sim 172$, 昭 39 (1964).

8）宫入裕夫，村松篤良：クラスプの変形々強度（第 1 報） 䳯尖に水平倚重を受ける立体状クラスプ，歯理工誌， 9 ： 15 23，昭 43 (1968).

9）宮入裕夫，村松篤良：クラスプの変形と強度（第 2 報） 鈎尖に垂直荷重を受ける立体状クラスプ, 歯理工誌, 9 ： 153 161，昭 43 (1968).

10) Ney, J.M. : Planned Partials, Conn., 1959, The J.M. Ney Co., $84 \sim 88$.

11）宮内孝雄，久保田英雄，関根 弘，安藤義夫：クラスプ の光弹性実験(第 1 報), 歯科学報, $59: 1243$, 昭34(1959).

12）村松篤良，安達和子 : Cast clasp の光弹性的応力解析, 歯材研報, $2: 484 \sim 490$, 昭 38 (1963).

13）奥野善彦：鋳造鈎の形態に関する力学的研究，阪大歯 誌, $13: 341 \sim 352$, 昭 43 (1968).

14）関根弘, 田島篤治, 柳川浩, 高梨恒一, 宮下恒太, 竹井正章: 義歯の力学的研究 (第 7 報) クラスプの力学 的考察 (その1), 補緅誌, $7: 83 \sim 88$, 昭 38 (1963).

15）関根 弘, 田島篤治, 柳川 浩, 高梨恒一, 竹井正章, 山田洋文, 溝上隆男 : 義歯の力学的研究 (第 8 報) クラ スプの力学的考察 (その 2 ), 補緅誌, $7: 169 \sim 175$, 昭 38 (1963).

16）杉山伸顕：鋳造鈎の維持力に関する研究，歯学， 52 : 97 114, 昭 39 (1964).

17) Firtell, D.N. : Effect of clasp design upon retention of removable partial dentures, J. Pros. Dent., $20: 43 \sim 52,1968$.

18）松田浩一：クラスプ用金属材料の機珹的性翼に関する研 究，第 2 報，鋳造クラスプの維持と弹性的性質について 口病誌, $42: 22 \sim 41$, 昭 50 (1975).

19）野首孝絽，堤 定美，山賀 保，奥野善彦：クラスプの 力学的研究, 第 1 報, 有限要素法の適用性, 補緅誌, 19 : $611 \sim 617$ 昭51 (1976).

20）西山 暲：鋳造鈎の維持力に関する実験的研究, 一Gingivally approaching clasp (I-bar tyep)について, 補緅誌，20 (揭载予定).

21) Jelenko, J.F. : Partial dentures, New York, 1966, J.F. Jelenko \& Co., Inc., $23 \sim 25$.

22）松尾悦郎：鋳造鈎の設計（理論編），菌界展望，18： 
456 464, 昭 36 (1961).

23）石上健次 : 鋳造銁の製造法，歯科特報，5:12 14, 昭 26 (1951).

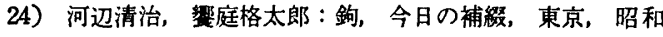
35, $190 \sim 200$ 頁, 医歯薬出版.

25）旗手 敏, 河野修己：鋳造鈎の基本形態と口ーチ鈎の作 り方，歯科技工講座，2，東京，昭和 44，143 162 頁， 医蒾薬出版.

26) Farrell, J. : Partial denture designing, London,
1971, Henry Kimpton Publishers, 58 60.

27）堤 定美，野首孝闹，山賀 保，山田隆司，西山 暲， 奥野善彦: 有限要素法による鋳造鈎の二次元弾塑性応力 解析，歯材器誌， $32: 95 \sim 102$, 昭 50 (1975).

28) Bates, J.F.: The mechanical properties of the cobaltchromium alloys and their relation to partial denture design, Brit. Dent. J., $119:$ 389 396 , 1965. 